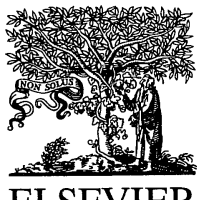

International Journal of Risk \& Safety in Medicine 7 (1995) 260-262

\title{
Contents, Volume 7
}

No. 1

April 1995

\section{Editorial}

The risk of biased patient information on prescription drugs K. Kimbel (Germany)

The pharmaceutical industry and the lay press: the industry's point of view A.M. Van Trigt, L.T.W. De Jong-van den Berg, J. Willems, Th.F.J. Tromp and F.M. Haaijer-Ruskamp (The Netherlands)

Monitoring of nilvadipine $\left(\right.$ Escor $\left.^{\mathrm{R}}\right)$ treatment of 23770 hypertensive patients H. Achenbach and P. Honerjäger (Germany)

Research in the Danish health service system: completeness and validity of prescription data, illustrated by analysis of utilization of oral anticoagulants

H.T. Sфrensen, F.H. Steffensen, E. Ejlersen, J. Mфller-Petersen and K. Kristensen (Denmark)

Beyond Belmont: critically assessing the adequacy of informed consent M.B. Kapp (USA)

Diagnostic methods in complementary medicine. Which craft is witchcraft? E. Ernst and Ch. Hentschel (UK, Germany)

\section{Case Commentary}

Treatment of an anencephalic infant: the case of Baby $\mathrm{K}$

B.R. Furrow and E.W. Clayton (USA) 
No. 2

October 1995

Special Issue

International Congress on Obesity Management;

from scientific approaches to individual experiences

Antwerp, 19-22 September 1993

\section{Editorial}

Obesity: taking safety seriously

G. Dukes (Denmark)

V

The treatment of obesity: a contemporary view

A.J. Stunkard (USA)

Obesity in Europe - causes, costs, and consequences J.C. Seidell (Netherlands)

The role of surgery in obesity management J.G. Kral (USA)

Human obesity: a medical assessment of health risks L.F. Van Gaal and I.H. De Leeuw (Belgium)

Nutrition and appetite control: implications for the regulation of body weight J.E. Blundell and S. Green (UK)

Dieting: the results of a "user-friendly" programme W. Burniat and C. Van Aelst (Belgium)

Obesity: translating scientific research into therapeutic and preventive benefit

W.P.T. James and A. Ralph (UK)

Conclusions

Management of obesity: from scientific approaches to individual experiences E. Helsing (Denmark)

No. 3

December 1995

Publisher's Note

\section{Editorial}

The role of efficacy and risk in analgesia

K.H. Kimbel (Germany) 


\section{Regular Papers}

Identification of cases of meningococcal disease: data quality in two Danish population-based information systems during a 14-year period H.T. Sørensen, I. Hansen, E. Ejlersen, H.C. Schønheyder, H. Hamburger and S. Sabroe (Denmark)

An investigation into the malfunctioning of specialists in Dutch hospitals $P$. Lens and G. Van der Wal (The Netherlands)

Patients' willingness to accept risks of medical intervention: intubation and ventilatory support for short periods of time D.J. Mazur and D.H. Hickam (USA)

Women's opinions on the use of folic acid E.R. Klok, Tj. Tijmstra, M.C. Cornel, H.E.K. De Walle and L.T.W. De Jongvan den Berg (The Netherlands)

Adverse drug reactions to herbal and synthetic expectorants E. Ernst, Ch. Sieder and R. März (UK, Germany)

Femoral pseudoaneurysms produced by percutaneous femoral procedures N. Levi and T.V. Schroeder (Denmark)

\section{Short Reports}

False aneurysm of the profunda femoral artery after intertrochanteric fracture of the femur

N. Levi and T.V. Schroeder (Denmark)

Vascular graft infections with Mycoplasma: an overlooked risk factor? N. Levi, J. Skov Jensen, J. Prag, J. Eiberg, J. Jørgensen and T.V. Schroeder (Denmark)

\section{Case Report}

Erroneous diagnosis of left ureteric injury leading to insertion of double $\mathbf{J}$ catheter to the left spermatic vein

Safety \& Risk in Practice

Book Reviews 